\title{
Characterization of fastidious adenovirus types 40 and 41 by DNA restriction enzyme analysis and by neutralizing monoclonal antibodies
}

\author{
Harrie G.A.M. van der Avoort ${ }^{1}$, Anton G. Wermenbol ${ }^{1}$, \\ Timo P.L. Zomerdijk ${ }^{1}$, John A.F.W. Kleijne ${ }^{1}$, Jack A.A.M. van Asten ${ }^{2}$, \\ Piet Jensma ${ }^{2}$, Albert D.M.E. Osterhaus ${ }^{3}$, \\ Alistair H. Kidd ${ }^{4}$ and Jan C. de Jong ${ }^{1}$ \\ ${ }^{1}$ Laboratorium voor Virologie, ${ }^{2}$ Rijkscontrolelaboratorium, ${ }^{3}$ Bijzondere Afdeling Immunobiologie, \\ Rijksinstituut voor Volksgezondheid en Milieuhygiene, 3720 BA Bilthoven, The Netherlands; \\ " Department of Virology, Auckland Hospital, Auckland 1, New Zealand
}

(Accepted 14 October 1988)

Summary

The DNA of 48 strains of adenovirus type 40 (Ad40) and of 128 strains of adenovirus type 41 (Ad41), isolated between 1971 and 1986 from various countries, was characterized by restriction enzyme analysis using nine and ten restriction endonucleases respectively. Five new DNA variants of Ad40 and 18 new DNA variants of Ad41 were detected. Most of the restriction sites which differed among the various DNA variants appeared to be distributed at random over the entire length of the viral genomes of the two serotypes. The number of restriction sites by which two DNA variants differed from each other was used as a measure of their relatedness. Several clusters of closely related DNA variants were observed for each of the two serotypes. The 35 DNA variants of Ad40 and Ad41 were used to test monoclonal antibody preparations for their range of reactivity in a neutralization assay. One monoclonal antibody (5-8), raised against Ad40 strain Dugan, showed type-specific neutralization of all 11 Ad40 DNA variants tested. Six monoclonal antibodies, raised against Ad41 strain Tak, neutralized different proportions of the variants of Ad41. Two of these preparations (1-21 and 3-19) neutralized all 24 Ad41 DNA variants, while a third (1-23) reacted with only 12 Ad41 variants. Three other monoclonal antibody preparations $(3-10,3-18,7-14)$ reacted specifically with only 6

Correspondence to: H.G.A.M. van der Avoort, RIVM, Laboratory of Virology, P.O. Box 1, 3720 BA Bilthoven, The Netherlands. 
of these 12 variants. The patterns of reactivity with the monoclonal antibody preparations correlated with the presence or absence of a HindIII restriction site at 56 map units and of an EcoRI restriction site at 52 map units on the Ad41 DNA. This region of the adenovirus DNA codes for the hexon protein, which is known to contain the type-specific neutralizing antigenic determinants.

Fastidious adenoviruses type 40 and 41 ; DNA restriction analysis; Virus neutralization; Monoclonal antibody

\section{Introduction}

The fastidious adenoviruses type 40 (Ad40) and type 41 (Ad41) are associated with infantile diarrhoea (Brandt et al., 1979; Retter et al., 1979; Uhnoo et al., 1984). Infection is accompanied by the shedding of very large numbers of virus particles (Flewett, 1976). Ad40 and Ad41 are closely related to each other in neutralization assays and are indistinguishable in haemagglutination-inhibition tests (De Jong et al., 1983). These serological properties, together with the high percentage of genome homology between the two types as shown in DNA hybridization experiments (Van Loon et al., 1985), justify the classification of Ad40 and Ad41 in one subgenus F, although the DNA restriction patterns of the two viral DNAs are remarkably dissimilar (Uhnoo et al., 1983). Restriction enzyme analysis has revealed the existence of at least six DNA variants within each of the two serotypes on examination of only 40 subgenus $F$ isolates (Kidd, 1984; Kidd et al., 1984). This large heterogeneity of the DNA can be useful in epidemiological studies, but may interfere with identification of fastidious adenoviruses by DNA restriction analysis (Buitenwerf et al., 1985).

By definition the serotyping of adenovirus isolates is done by neutralization tests. However, the high degree of cross-reactivity of polyclonal antisera to Ad40 and Ad41 (De Jong et al., 1983) precludes rapid assignment of new isolates to one or other serotype by this method. Typing by ELISA using polyclonal antibodies is not possible because of group reactivity, unless the reagents are absorbed with antigens of the other cross-reacting serotypcs (Johansson et al., 1980, 1985). Monoclonal antibodies have been used already for the detection and typing of fastidious adenoviruses, directly in stool specimens by enzyme-immuno assays (Singh Naz and Naz, 1986; Hermann et al., 1987a, b; Singh Naz et al., 1988). In the present study monoclonal antibodies are described which neutralized all DNA variants of Ad40 or Ad41 tested and which can be used to type isolates by neutralization assay on a routine basis.

\section{Materials and Methods}

\section{Viruses and monoclonal antibodies}

The present study involves 176 strains of Ad40 or Ad41. All were isolated between 1971 and 1986 from the faeces of young children with diarrhoea in various 
TABLE 1

Origin of strains

\begin{tabular}{|c|c|c|c|c|c|}
\hline \multirow[t]{2}{*}{ Origin } & \multicolumn{2}{|l|}{ Ad40 } & \multicolumn{2}{|l|}{ Ad41 } & \multirow[t]{2}{*}{ Provided by } \\
\hline & Number & $\begin{array}{l}\text { Year of } \\
\text { isolation }\end{array}$ & Number & $\begin{array}{l}\text { Year of } \\
\text { isolation }\end{array}$ & \\
\hline \multicolumn{6}{|l|}{ Europe } \\
\hline The Netherlands & 21 & 1971-1985 & 66 & $1973-1986$ & \\
\hline Belgium & 7 & $1984-1985$ & 9 & $1984-1986$ & G. Zissis, Brussels \\
\hline \multirow[t]{3}{*}{ U.K. } & 2 & 1975,1978 & 8 & $1976-1979$ & \\
\hline & 2 & 1985 & 8 & $1984-1985$ & D. Wood, Manchester \\
\hline & & & 2 & 1983 & U. Desselberger, Glasgow \\
\hline F.R.G. & 3 & 1980 & 8 & $1979-1980$ & R. Wigand, Hamburg \\
\hline Norway & & & 1 & 1981 & I. Ørstavik, Oslo \\
\hline Sweden & 1 & 1982 & 3 & $1976-1982$ & G. Wadell, Umea \\
\hline Finland & 1 & 1975 & & & G. Wadell, Umea \\
\hline Spain & 2 & 1985 & & & J. Pereira, Madrid \\
\hline Portugal & & & 2 & 1984 & C. Caneiro, Lisbon \\
\hline \multicolumn{6}{|l|}{ Asia } \\
\hline Malaysia & & & 3 & 1978 & Ken Lam, Kuala Lumpur \\
\hline \multicolumn{6}{|l|}{ Africa } \\
\hline R.S.A. & 5 & 1983 & 7 & $1980-1983$ & \\
\hline Tanzania & 1 & 1977 & & & \\
\hline \multicolumn{6}{|l|}{ America } \\
\hline \multirow[t]{2}{*}{ USA } & 1 & 1977 & 8 & $1976-1981$ & J. Hierholzer, Atlanta \\
\hline & & & 1 & 1983 & S. Strauss, Bethesda \\
\hline \multirow[t]{2}{*}{ Canada } & 1 & 1983 & & & M. Brown, Toronto \\
\hline & 1 & 1981 & 1 & 1981 & P. Blaskovic, Toronto \\
\hline Colombia & & & 1 & 1982 & \\
\hline Total & 48 & & 128 & & \\
\hline
\end{tabular}

countries. Each strain came from a different patient. The Dutch patients lived in various parts of the country and were not epidemiologically related, with three exceptions: three Ad41 strains were isolated from three children who contracted gastroenteritis on the same day during their stay in the same paediatric clinic of a Dutch hospital. The origin of the strains from outside The Netherlands is shown in Table 1. Several strains have been described earlier, notably Ad40 strains Hovi X (De Jong et al., 1983; Jacobsson et al., 1979; Johansson et al., 1980), Münster 3415-80 (De Jong et al., 1983; Takiff et al., 1984), Dugan (De Jong et al., 1983) and Ad41 strains Tak (De Jong et al., 1983; Kidd, 1984), N597 (De Jong et al., 1983), 26341 (Kidd et al., 1983; Kidd, 1984), Br690 (De Jong et al., 1983; Kidd, 1984), and G1105 (Takiff et al., 1984) and the strains from South Africa (Kidd, 1984; Kidd et al., 1984). The virus strains had been typed by standard serum neutralization assays (De Jong et al., 1983) using rabbit antisera, horse antisera or monoclonal antibodies.

Monoclonal antibodies were prepared using standard procedures (Osterhaus et al., 1981, 1984), with adenovirus type 40 strain Dugan and adenovirus type 41 Tak 
as immunogens. Details on the selection and characterization of the type-specific neutralizing monoclonal antibodies will be described elsewhere (De Jong et al., in preparation).

\section{$D N A$ restriction enzyme analysis}

Virus DNA was extracted from infected Graham 293 cells by a combination of a modified Hirt method (Hirt, 1967; Wadell and De Jong, 1980) and the procedure described by Buitenwerf et al. (1985).

All restriction endonucleases were from Boehringer Mannheim GmbH, Mannheim, F.R.G. Incubations were performed according to the instructions of the manufacturer. Electrophoresis was performed in $0.8 \%(\mathrm{w} / \mathrm{v})$ agarose gels, as described earlier (Van der Avoort et al., 1986). A fragment mixture of HindIII-cleaved lambda DNA (Boehringer Mannheim $\mathrm{GmbH}$ ) was also present on each gel, providing 8 markers for molecular weight determinations, measuring: $23606,9636,6636$, $4333,2257,1985,561$ and $139 \mathrm{bp}$. The DNA variants were named according to the nomenclature rules described for Ad21 and Ad6 DNA variants (Van der Avoort et al., 1986; Adrian et al., 1985). Restriction site mapping was done by double digestions on complete viral DNAs or on isolated DNA fragments. Hybridization experiments were performed as described earlier using cloned DNA fragments as probes for the detection of homologous sequences on nitrocellulose filters, obtained after Southern blotting of agarose gel separated DNA digests (Takiff et al., 1984; Kidd et al., 1984).

The same differences in restriction profiles of the DNA of the various strains were observed in both laboratories participating in the present study despite different patterns in the cultivation history of the strains. Furthermore, Ad40 or Ad41 DNA which was isolated directly from the original stool specimens always showed the same restriction patterns as the DNA obtained by cell cultivation.

\section{Clustering of adenovirus DNA variants}

The differences between the DNA variants were analyzed with the so-called Theoretical Pattern Fitting computer program, which has been applied already to the comparison of poliovirus and influenzavirus strains (Osterhaus et al., 1983, 1984; Weijers et al., 1985). For each pair of DNA variants the number of restriction enzyme site differences which separated these variants was established and used as coordinates in an imaginary multi-dimensional space. The Euclidean distance between two DNA variants was calculated as the square root of the sum of the squared differences of the coordinates divided by the number of DNA variants involved. By use of a taxonomic cluster procedure (Sokal and Sneath, 1963) the DNA variants were grouped and aligned, thus allowing a graphical illustration of the data.

\section{Results}

DNA restriction enzyme analysis

The DNAs of 48 Ad40 strains and 128 Ad41 strains were characterized by restriction enzyme analysis using endonucleases BamHI, BglI, BstEII, EcoRI, 


\section{BamHI BglI BstEII EcoRI HindIII KpnI Sac I Smal XhoI}

Ad 40
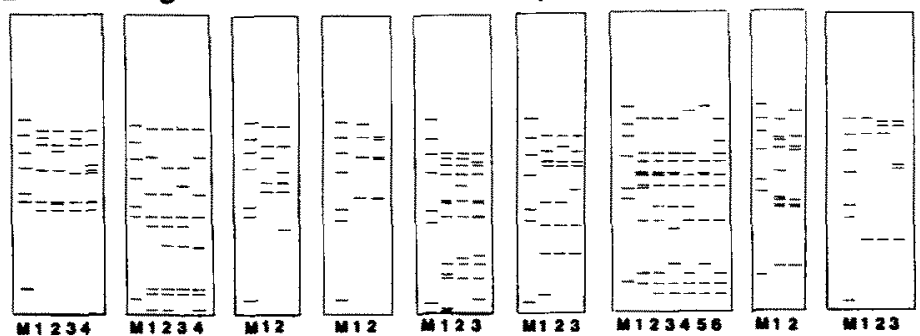

BamHI BglI BstEI EcoRI

Hind III KpnI
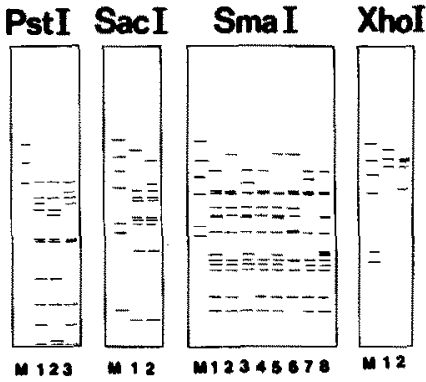

\section{BamHI BglI BstEII EcoRIHindIII KpnI Sac I SmaI XhoI}

$\operatorname{Ad} 40$
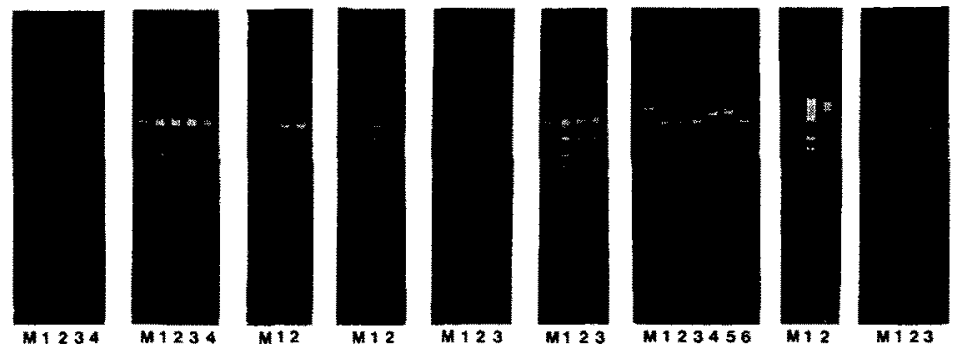

BamHI
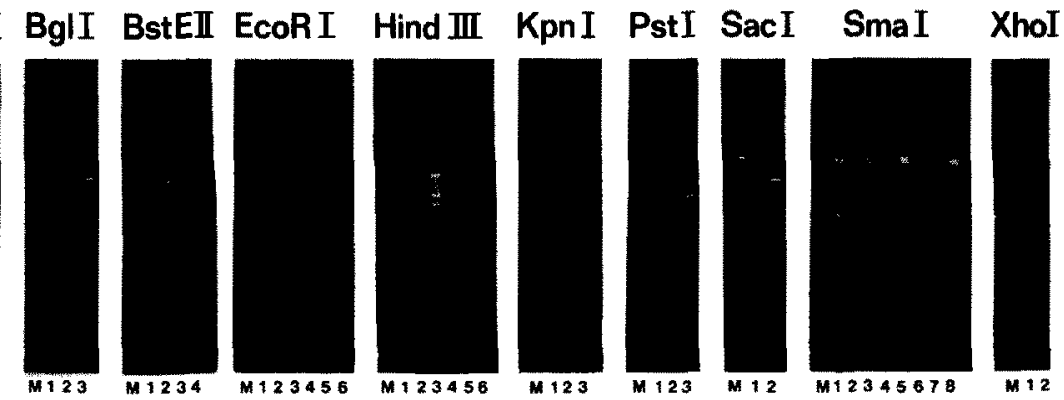

Fig. 1. Restriction enzyme patterns of Ad40 and Ad41 isolates. For each of the indicated restriction enzymes, the pattern obtained with the prototype strains Hovi X (Ad40) and Tak (Ad41) was labeled 1. All different patterns were numbered consecutively (Tables 2 and 3). In each panel, the lane labeled $M$ contains a $\lambda D N A-H i n d I I I$ digest as marker for molecular weight determination. 


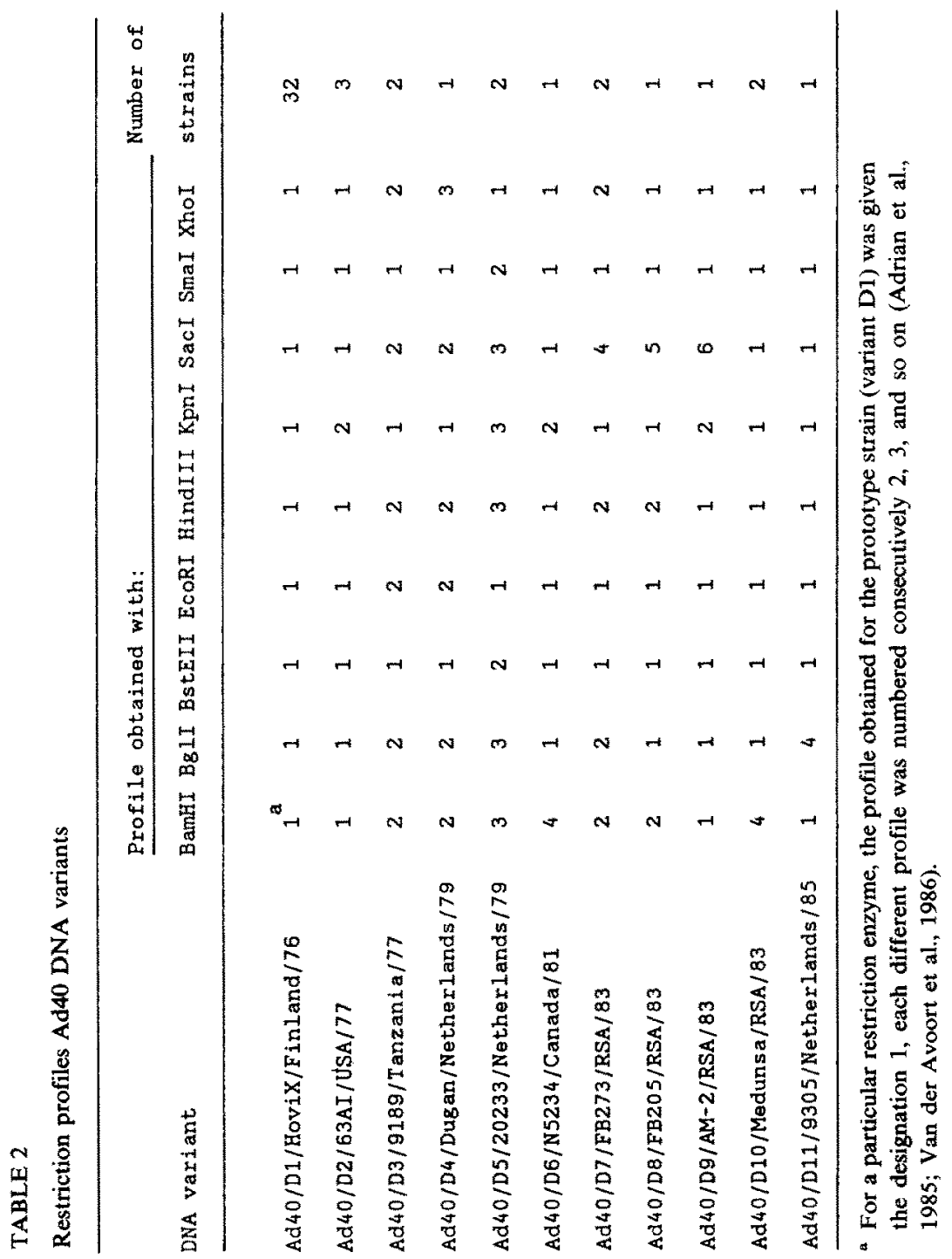




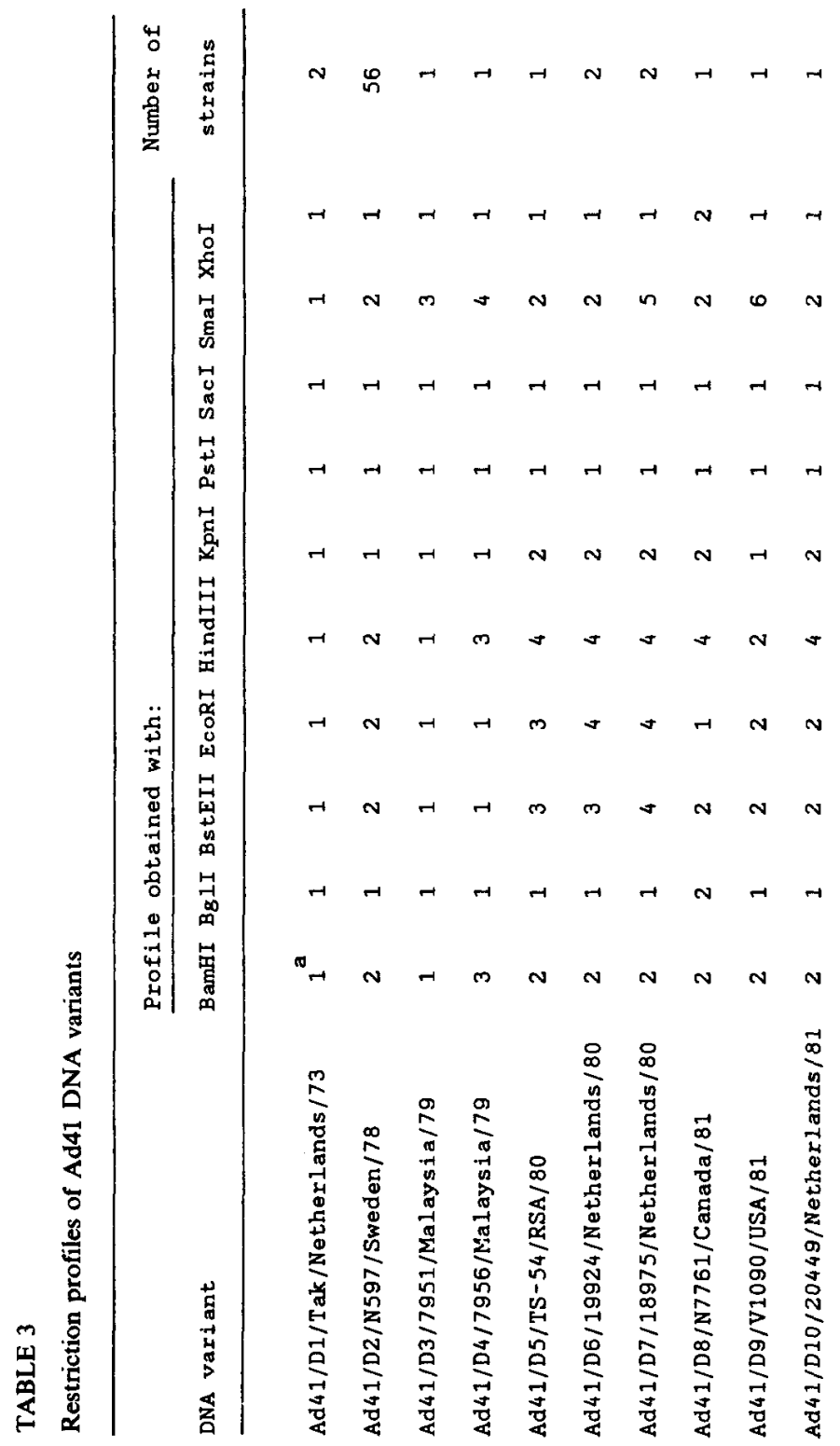




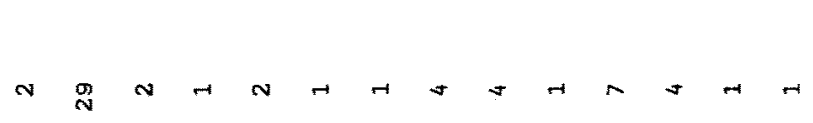

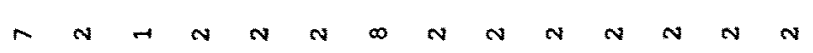

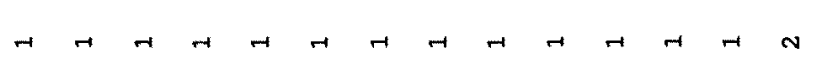

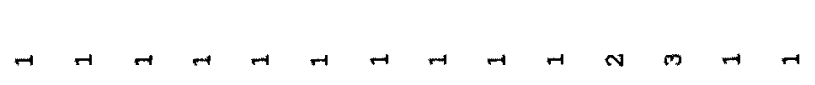

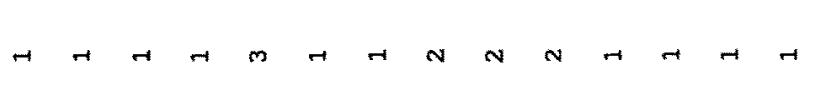

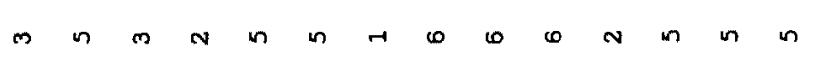

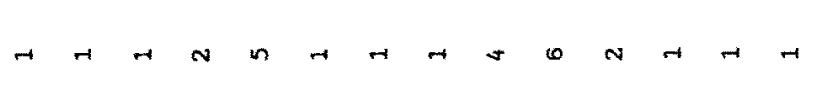

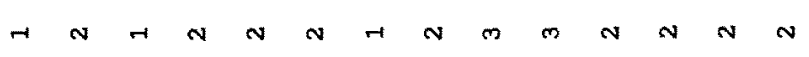

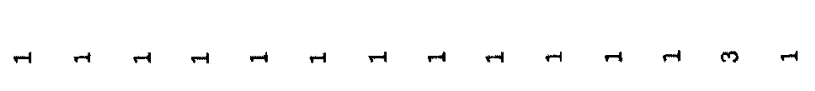

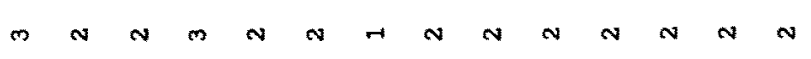

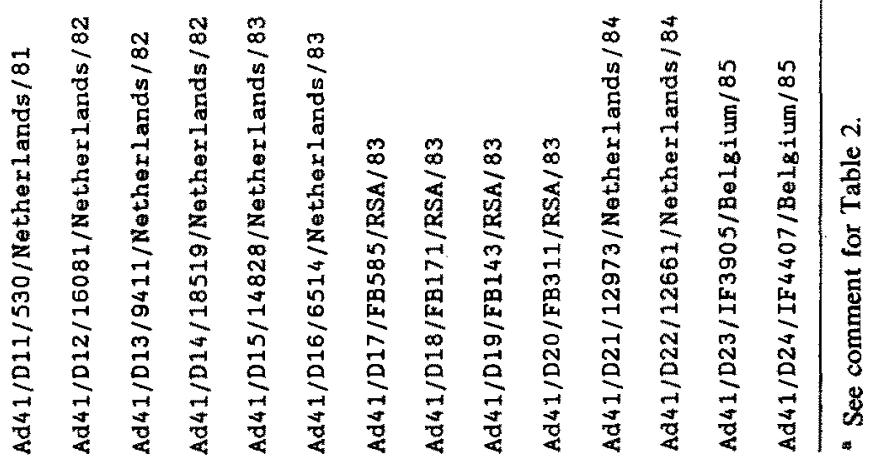


HindIII, KpnI, PstI (only for Ad41), SacI, SmaI and XhoI. The DNA analysis confirmed in all cases the results obtained by typing of the isolates in neutralization tests. For each of these enzymes, differences between the restriction profiles of the DNA of various strains from both serotypes were observed (Fig. 1). Ad40 strain Hovi X, isolated in Finland in 1976, and Ad41 strain Tak, isolated in The Netherlands in 1973, were considered to be prototype strains against which all combinations of restriction profiles were compared (Tables 2 and 3). Eleven DNA variants of Ad40 and 24 DNA variants of Ad41 were detected. There was an unequal distribution of the strains over the various DNA variants. Three variants were predominant: Ad40 DNA variant D1, corresponding to the prototype strain and comprising two thirds of the Ad40 strains, and two Ad41 DNA variants D2 and D12, comprising $40 \%$ and $20 \%$ of the Ad41 strains respectively. For each of the other Ad40 and Ad41 DNA variants, only one or a few representative strains were present in our collection. Since its first appearance in 1982, Ad41 DNA variant D12 was observed in a continuously growing proportion of the Ad41 strains isolated in The Netherlands.

The total length of each of the viral DNAs as measured by gel electrophoresis of the complete genome and by summation of the lengths of restriction fragments was approximately $35000 \mathrm{bp}$ in all cases. There was thus no evidence for large deletions or insertions in any of the DNA variants studied. The DNA digestion patterns of two Ad40/D1 isolates, namely strain Münster 3415-80 and strain 85-11308 from Great Britain, showed several bands of submolar intensity next to the normal fragments for Ad40 DNA variant D1, indicating incomplete DNA molecules (data not shown). These incomplete molecules constituted $80 \%$ of the isolated viral DNA and lacked some $800 \mathrm{bp}$ at the left end of the viral genome (Fig. 2). This phenomenon has been described earlier for Ad40 strain Dugan VR931 (Takiff et al., 1984). The restriction maps in that paper are, however, identical to Ad40 variant D1. Strain Dugan in our hands was identical to Ad40 DNA variant D4 and showed no incomplete DNA molecules, nor did any of the other Ad40 strains in the present study except strains Münster 3415-80 and 85-11308. So probably an inadvertent exchange of strains did take place, as was also suggested by others (Wadell et al., 1987).

With the set of restriction enzymes used in the present investigation, more than 70 restriction sites in Ad40 DNA and more than 90 sites in Ad41 DNA could be monitored. Twenty-five mutations were responsible for the differences in restriction profiles of the 11 Ad40 DNA variants and 27 mutations were responsible for the differences between the 24 Ad41 DNA variants. Most of these mutations could be mapped unequivocally on the viral genomes by double digestions with restriction enzymes. The physical map of the viral DNA was either known already from the literature (Van Loon et al., 1985; Takiff et al., 1984; Allard et al., 1985) or was newly constructed by double digestions and DNA hybridization studies: for example, the BglI and SacI map of Ad40, and the BglI, BstEII, PstI and SacI map of Ad41 (Figs. 2 and 3). Two mutations could not be localized exactly. Ad40 mutation $\mathrm{H}_{4}$ mapped within one of the two 850 bp HindIII fragments located at 61 map units or 90 map units, and Ad41 mutation $A_{3}$ mapped near one of the ends of the 


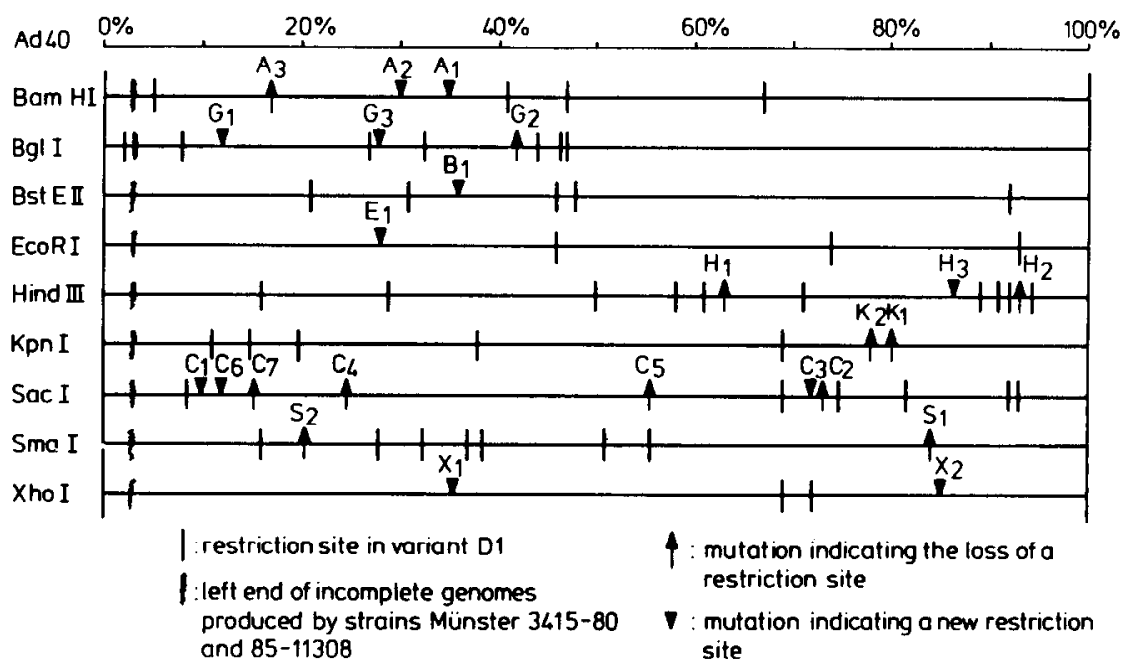

Fig. 2. Restriction map of Ad40 DNA (strain Hovi X). The restriction sites which are different in the various DNA variants are indicated with a capital and a subscript. A, mutations in the Bam HI pattern; B, in the BstEII pattern; C, in the SacI pattern; E, in the EcoRI pattern; G, in the BglI pattern; H, in the HindIII pattern; $\mathrm{K}$, in the KpnI pattern; $\mathrm{P}$, in the Pst I pattern (only for Ad41); $\mathrm{S}$, in the SmaI pattern; and $\mathrm{X}$, in the XhoI pattern.

$1320 \mathrm{bp}$ Bam HI fragment located itself at 30 map units. For both serotypes, the mutations appeared to be distributed at random over the entire length of the viral genomes. The occurrence of the various mutations in the DNA variants is summarized in Tables 4 and 5. Several mutations, for example Ad41 mutations $A_{1}, B_{1}$, $\mathrm{H}_{1}, \mathrm{H}_{2}, \mathrm{~S}_{1}$, and $\mathrm{S}_{2}$ occurred in almost all the DNA variants, indicating a close

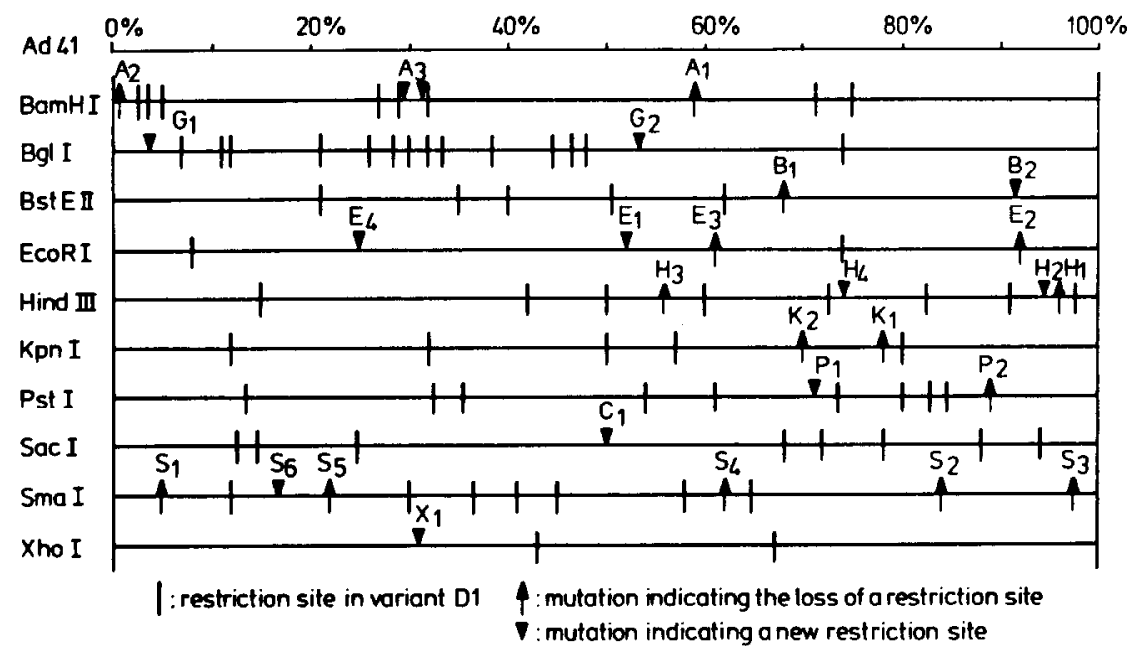

Fig. 3. Restriction map of Ad41 DNA (strain Tak). Abbreviations are as in Fig. 2. 


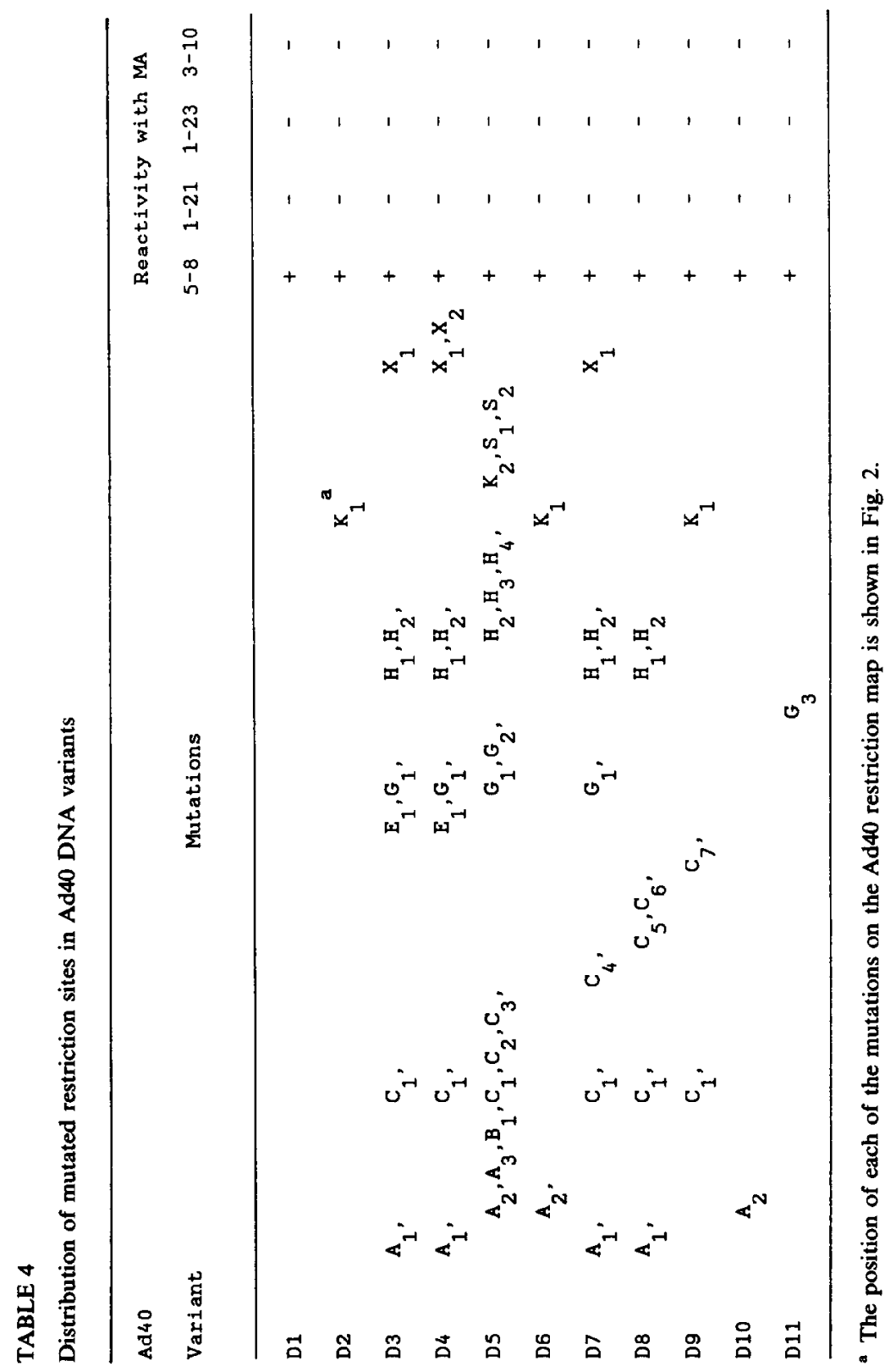




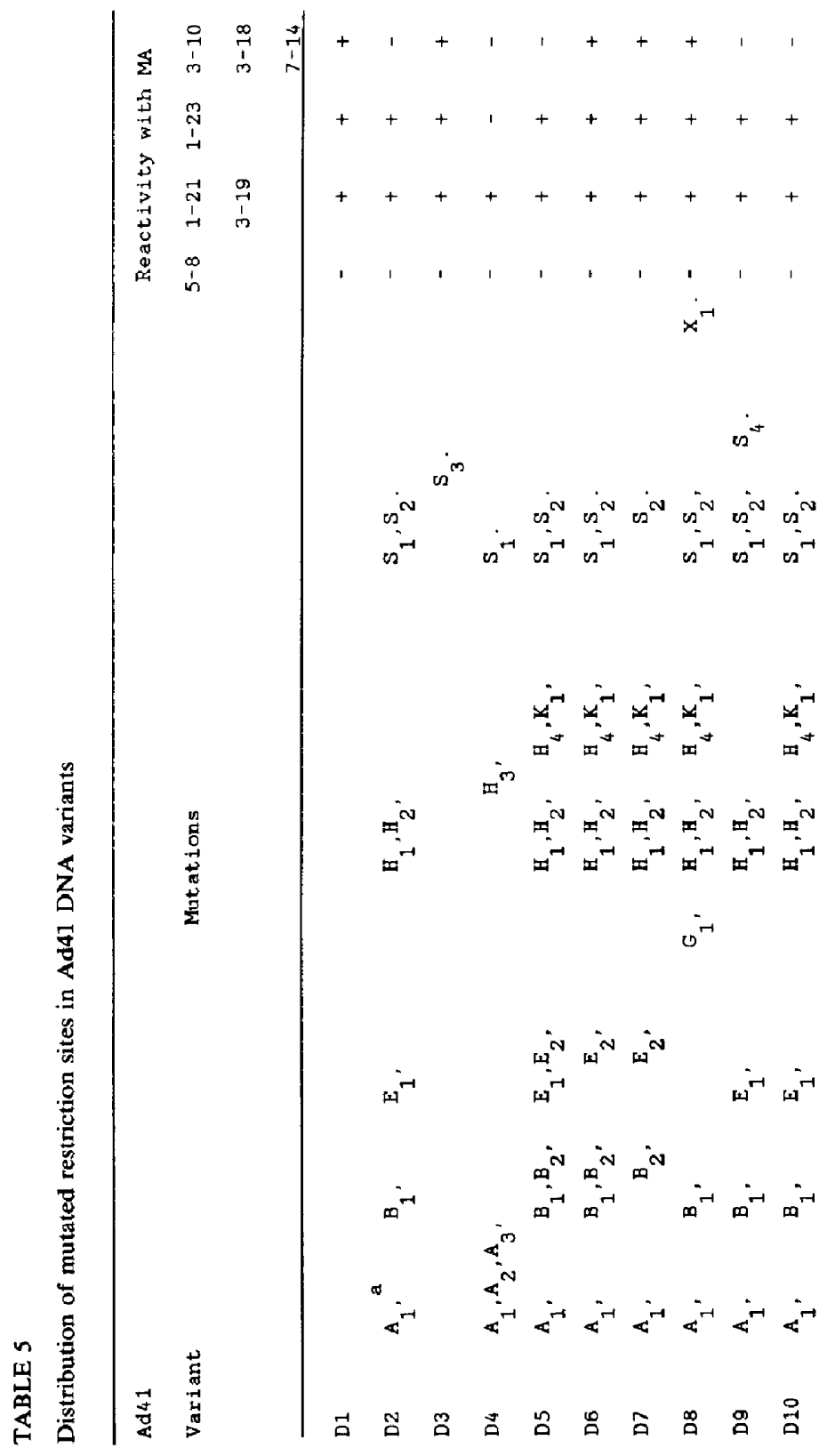


$i^{\text {in }}$

$$
i^{-1}
$$

$\sin _{n} \sin ^{-1} \cos ^{-1} \sin ^{-1} \cos ^{-1}$

$$
\begin{aligned}
& \cos ^{-1} \sin ^{-1} \cos ^{-1} \cos ^{-1} \sin ^{-1} \cos ^{-1} \cos ^{-1} \\
& a^{-1}
\end{aligned}
$$

$x^{2}$

$$
x^{-1} x^{-1-1}
$$

$x^{m} x^{m} x^{m} a^{m}$

$a^{m} x^{m}$

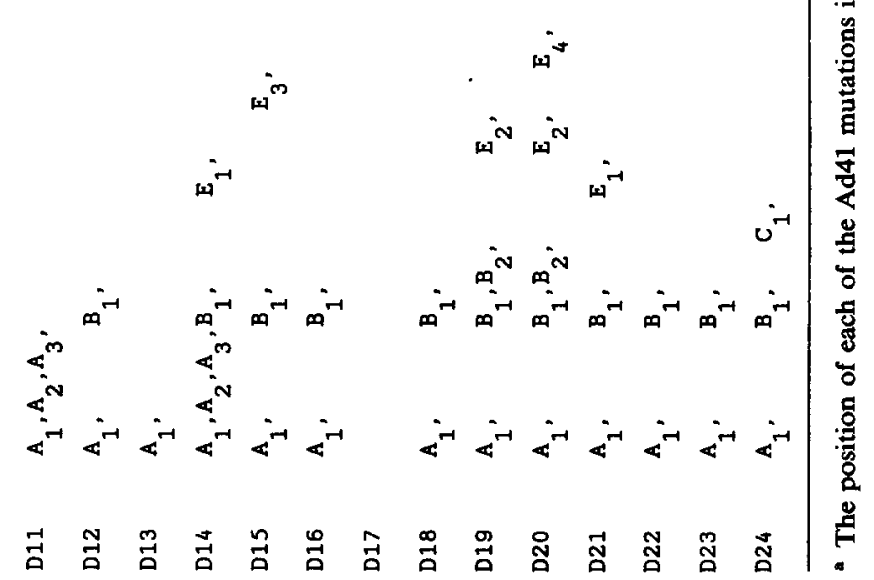


Numerical taxonomy of Ad40 DNA variants.

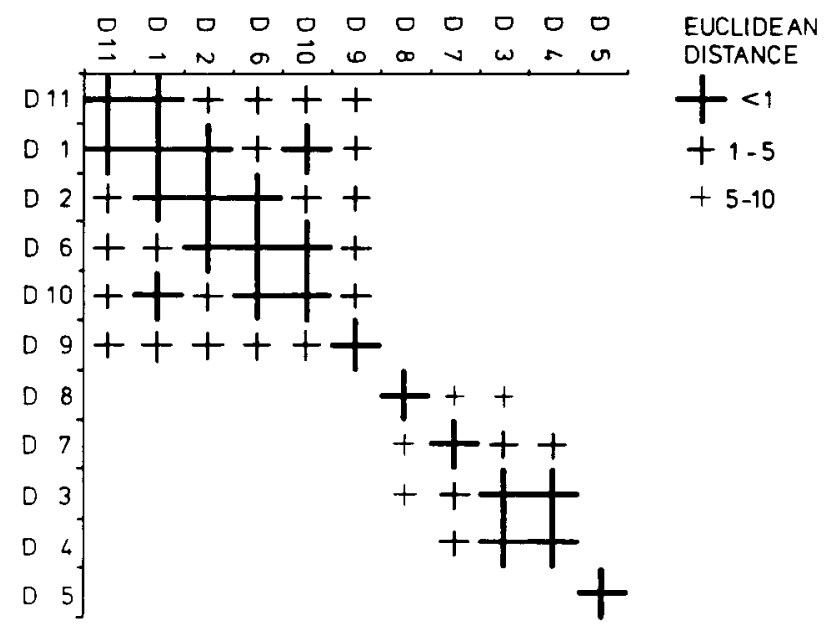

Fig. 4. Numerical taxonomy of Ad40 DNA variants. The mutual relatedness of the various Ad40 DNA variants is expressed as a Euclidean distance (E.D.), which was calculated using the number of mutations differing between the DNA variants as coordinates (see Materials and Methods). A low E.D. reflects a close relationship, a high E.D. illustrates a more distinct relationship between two DNA variants. Blank areas indicate a E.D. of $>10$.

evolutionary relationship between these variants. Other mutations were observed in just one DNA variant. For example, $E_{3}$ for Ad41 DNA variant D5 and $G_{1}$ for Ad41 variant D8 could be used as an epidemiological marker for these strains.

To express the relationships among the various DNA variants in a more quantitative way, a computerized taxonomic cluster procedure (Osterhaus et al., 1983, 1984; Weijers et al., 1985) was used, based on the difference in number of Inutations between two variants. The mutual distinction of two variants was expressed as a Euclidean distance (E.D.). A low Euclidean distance (E.D. < 1) indicated a strong relationship between two variants, while two distinct strains were characterized by a high Euclidean distance (E.D. > 10).

For Ad40, two clusters of DNA variants could be distinguished (Fig. 4). Variants D2, D6, D9, D10 and D11 were strongly related to reference strain Hovi X (variant D1), whereas the variants D3, D7 and D8 formed another cluster around strain Dugan (variant D4). The two clusters differed by the mutations $A_{1}, H_{1}$ and $\mathbf{H}_{2}$. Variant D5 with ten exclusive mutations was clearly separate from both clusters (mean E.D. $=36$ ).

For Ad41 three clusters were found (Fig. 5). The first comprised 6 DNA variants which were strongly related to Ad41 reference strain Tak (variant D1) and were clearly distinct from all other variants (mean E.D. $=29$ ). Characteristic for this cluster was the absence of mutations $\mathrm{H}_{1}, \mathrm{H}_{2}$ and $\mathrm{S}_{2}$. This last mutation represents the distinction between Ad41 prototype strains and Ad41a strains in earlier literature (Buitenwerf et al., 1985; Kidd et al., 1983). The other Ad41 DNA variants 
Numerical taxonomy of Ad41 DNA variants.

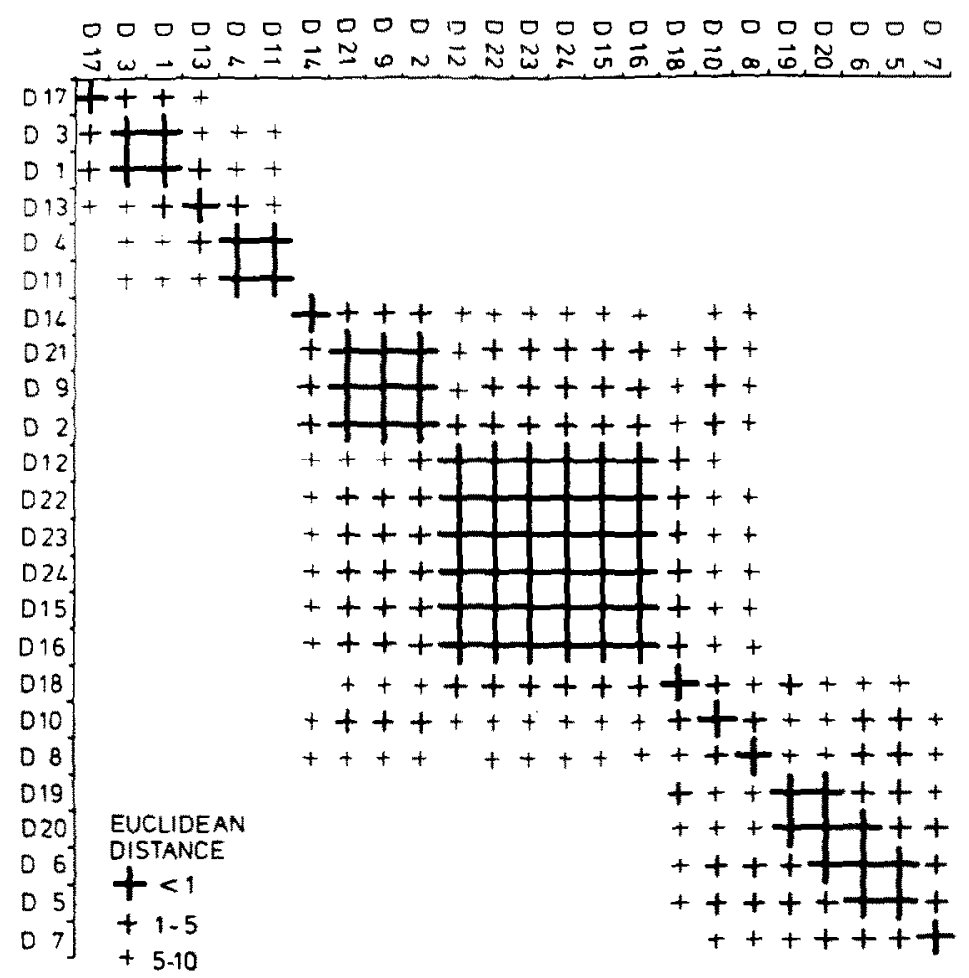

Fig. 5. Numerical taxonomy of Ad41 DNA variants. For comments, see legend to Fig. 4.

constituted two distinct clusters of 5 and 10 variants with a relatively low relatedness to each other (mean E.D. - 19). The mutations $B_{2}, E_{2}, H_{4}$ and $K_{1}$ were characteristic differences between two clusters. Three DNA variants, D8, D10 and D18, were intermediates with mutations signifying relatedness to both of the latter two clusters.

The present set of fastidious adenoviruses is too small to allow firm conclusions about the relative occurrences of the DNA variants in the various countries. However, epidemiological observations can be made about the strains from The Netherlands.

The relative proportion of the two serotypes Ad40 and Ad41 in the total number of subgenus $\mathrm{F}$ adenovirus isolates did change remarkably over the period 1975-1988. Until 1981, Ad40 was isolated most frequently, but in more recent years Ad41 prevailed (De Jong et al., submitted). Furthermore, the Ad41 variant D12 variant was detected first in 1982 in The Netherlands and Belgium, increased in frequency, and now appears to be the dominating Ad41 variant in these countries. In some cases, DNA restriction enzyme analysis was helpful in tracing routes of infection. Three Ad41 strains were isolated from different children who got gastroenteritis on 
TABLE 6

Neutralization of Ad40 and Ad41 DNA variants by monoclonal antibodies

\begin{tabular}{|c|c|c|c|c|c|c|c|c|}
\hline \multirow{2}{*}{$\begin{array}{l}\text { Number } \\
\text { of strains }\end{array}$} & \multirow{2}{*}{$\begin{array}{l}\text { DNA } \\
\text { variant }\end{array}$} & \multicolumn{7}{|c|}{ Mean ${ }^{10} \log$ neutralization titer ${ }^{a}$ of } \\
\hline & & $\overline{5-8^{b}}$ & $1-21$ & $3-19$ & $1-23$ & $3-10$ & $3-18$ & $7-14$ \\
\hline Ad40: 48 & $\begin{array}{l}\text { D1, D2, D3, D4, D5, D6, } \\
\text { D7, D8, D9, D10, D11 }\end{array}$ & 6.0 & $--^{c}$ & - & - & - & - & - \\
\hline Ad41: 9 & D1, D3, D6, D7, D8, D17 & - & 3.3 & 2.0 & 3.2 & 4.4 & 5.2 & 4.9 \\
\hline Ad41: 67 & D2, D5, D9, D10, D14, D21 & - & 3.3 & 1.9 & 3.8 & - & - & - \\
\hline Ad41: 52 & $\begin{array}{l}\text { D4, D11, D12, D13, D15, D16, } \\
\text { D18, D19, D20, D22, D23, D24 }\end{array}$ & - & 3.1 & 1.8 & - & - & - & - \\
\hline
\end{tabular}

a All 176 strains were tested with a single dilution of each of the neutralizing MAbs. For a group of strains including representatives of all DNA variants of both serotypes the various antibody preparations were also titrated. As systematic differences in neutralization titres between the various DNA variants were observed, the mean value for all neutralization tests by a particular antibody was calculated.

b MAb 5-8 was raised against Ad40 strain Dugan, the other six MAbs were prepared against Ad41 strain Tak.

${ }^{c}$ means $<1.0$.

the same day during their stay in the same paediatric clinic. All belonged to DNA variant $\mathrm{D} 22$, which is strong evidence for a common source of infection.

Neutralization of Ad40 and Ad41 DNA variants by monoclonal antibodies

Monoclonal antibodies (MAb) were prepared by standard procedures using Ad40 strain Dugan and Ad41 strain Tak separately as immunogens. Seven MAb preparations were found to have neutralizing properties with one of the two serotypes. These neutralizing MAb preparations were used at a fixed screening dilution (usually $1: 10$ ) to test their reactivity with all $48 \mathrm{Ad} 40$ and 128 Ad41 strains of the present investigation. In addition neutralization titers of these MAbs were determined against several strains including representatives of all DNA variants from both serotypes. The results are shown in Table 6.

MAb 5-8, which was raised against Ad40, neutralized all 48 Ad40 strains. All Ad41 strains could not be neutralized with this MAb. The other six neutralizing MAbs were raised against Ad41 strain Tak, and reacted only with Ad41 strains. At the screening dilution of the monoclonals, all strains of the same DNA variant tested identical. Among the 24 Ad41 DNA variants three different neutralization patterns were observed (Table 5). Twelve variants were only neutralized by MAb 1-21 and MAb 3-19, six variants also reacted with MAb 1-23, while six other variants were neutralized by all six MAb preparations. The differences in reactivity of the DNA variants appeared to be correlated with the presence or absence of two restriction sites. The DNA variants of Ad41 which were only neutralized by MAb 1-21 and MAb 3-19 had the HindIII mutation $\mathrm{H}_{3}$ in common, while only those variants which had the Eco RI mutation $\mathrm{E}_{1}$ were neutralized by MAbs 1-21, 3-19 and 1-23, hut not by MAbs 3-10, 3-18 and 7-14. These two mutations, $E_{1}$ and $\mathbf{H}_{3}$, mapped at respectively 52 and 56 map units on the Ad41 viral genome. 


\section{Discussion}

The heterogeneity of adenovirus DNA, even within a single serotype has become a well known feature (Van der Avoort et al., 1986; Adrian et al., 1985; Wigand and Adrian, 1986; Wadell et al., 1985). Six DNA variants have been described already for each of the fastidious adenovirus serotypes 40 and 41 (Kidd, 1984; Kidd et al., 1984). The present analysis with 9 (Ad40) or 10 (Ad41) restriction enzymes revealed the existence of at least five other DNA variants of Ad40 and of 18 other DNA variants of Ad41 in a panel of 176 subgenus F strains.

Most the restriction sites which differed among the various strains could bc localized on the physical maps of the two DNAs. The results were in agreement with previously published restriction maps (Takiff et al., 1984; Allard et al., 1985) and DNA sequences of Ad40 and Ad41 (Van Loon et al., 1987). Although these restriction sites were found to be randomly distributed over the viral genomes, it was observed especially for Ad41 DNA variants that certain mutations which occurred only in fixed combinations (i.e. $\mathrm{H}_{1}$ and $\mathrm{H}_{2}, \mathrm{~B}_{2}$ and $\mathrm{E}_{2}$ and also $\mathrm{H}_{4}$ and $\mathbf{K}_{1}$ ) also mapped a very close distance (1-3\%) to each other in the physical map. Whether or not the proximity of these mutated restriction sites indeed reflects a more dramatic change in the corresponding DNA sequences can only be concluded after a more detailed analysis of the DNA sequences involved.

The restriction sites involved in the present investigations represented only one percent of the total genome. It is therefore remarkable that the reactivity of the various DNA variants to the different neutralizing Ad41 MAbs could be linked to the presence or absence of two restriction sites, EcoRI site $\mathrm{E}_{1}$ and HindIII site $\mathrm{H}_{3}$, located at 52 and 56 map units respectively. With Ad2 and Ad5, two adenovirus serotypes for which a detailed structure of the viral DNA is known, the coding sequence for the hexon protein is located between map units 51.6 and 59.7 (Akusjärvi and Petterson, 1978a, b). The hexon protein bears the type-specific neutralizing antigenic determinants (Norrby, 1969). Recent work (Toogood and Hay, submitted) has shown that for Ad41 this region of the viral DNA also codes for the hexon protein. The present results suggest that the two mutations mentioned are indeed located in the gene coding for the 'neutralizing' antigen. The existence of three different neutralizing MAbs implies that the latter antigen at least contains three different epitopes. These neutralizing MAbs should be helpful tools for the exact characterization of these epitopes.

Several MAbs used in this study reacted only with part of the strains of the corresponding type. This observation has to be taken into account when preparing diagnostic tests based upon such MAbs. At present MAbs 5-8 (Ad40) and 1-21 and 3-19 (both Ad41) can safely be used for this purpose. However, even when a MAb is broadly reactive at present, this does not necessarily mean that it will do so forever. This is illustrated by MAb 1-23, which neutralized almost all of the strains of Ad41 isolated in The Netherlands before 1982, and only about half of such strains isolated thereafter. This change occurred at the same time as the emergence of DNA variant Ad41/D12 in 1982. Apparently Ad41 shows a succession of DNA variants with time, like Ad7 (Wadell et al., 1981, 1985) and Ad21 (Van der Avoort et al., 1986). 
Unlike Ad7 and Ad21, the change in Ad41 was shown to involve a neutralizing epitope. In this way Ad41 variation resembles the antigenic drift of influenza virus. The fact that changes have been observed in at least two antigenic determinants involved in virus neutralization has important implications for the preparation of a vaccine to prevent severe infantile diarrhoea caused by Ad40 and Ad41. Thus the choice of a single vaccine strain might not be possible on a global level and might not remain valid in individual regions indefinitely.

\section{References}

Adrian, T., Best, B. and Wigand, R. (1985) A proposal for naming adenovirus genome types, exemplified by adenovirus type 6. J. Gen. Virol. 60, 2685-2691.

Akusjärvi, G. and Pettersson, U. (1978a) Sequence analysis of adenovirus DNA I. Nucleotide sequence at the carboxy-terminal end of the gene for adenovirus type 2 hexon. Virology 91, 477-480.

Akusjärvi, G. and Pettersson, U. (1978b) Nucleotide sequence at the junction between the coding region of the adenovirus 2 hexon messenger RNA and its leader sequence. Proc. Natl. Acad. Sci. USA 75, $5822-5826$.

Allard, A.K., Wadell, G., Fvander, K.M. and I.indman, G.K.K. (1985) Specific properties of two enteric adenovirus 41 clones mapped within early region 1 A. J. Virol. 54, 145-150.

Brandt, C.D., Kim, H.W., Yolken, R.M., Kapikian, A.Z., Arrobio, J.O., Rodriquez, W.J., Wyatt, R.O., Chanock, R.M. and Parrott, R.M. (1979) Comparative epidemiology of two rotavirus serotypes and other viral agents associated with pediatric gastroenteritis. Am. J. Epidemiol. 110, 243-254.

Buitenwerf, J., Louwerens, J.J. and De Jong, J.C. (1985) A simple and rapid method for typing adenovirus 40 and 41 without cultivation. $J$. Virol. Methods 10,39-44.

De Jong, J.C., Wigand, R., Kidd, A.H., Wadell, G., Kapsenberg, J.G., Muzerie, C.J., Wermenbol, A.G. and Firtzlaff, R.G. (1983) Candidate adenovirus 40 and 41 : fastidious adenovirus from human infantile stool. J. Med. Virol. 11, 215-231.

Flewett, T.H. (1976) Diagnosis of enteritis virus. Proc. R. Soc. Med. 69, 693-696.

Hermann, J.E., Perron-Henry, D.M. and Blacklow, N.R. (1987a) Antigen detection with monoclonal antibodies for the diagnosis of adenovirus gastroenteritis. J. Infect. Dis. 155, 1167-1171.

Hermann, J.E., Perron-Henry, D.M., Stobbs-Walro, D. and Blacklow, N.R. (1987b) Preparation and characterization of monoclonal antibodies to enteric adenovirus types 40 and 41. Arch. Virol. 94, 259-265.

Hirt, B. (1967) Selective extraction of polyoma DNA from infected mouse cell cultures. J. Mol. Biol. 26, $365-369$.

Jacobsson, P.A., Johansson, M.E. and Wadell, G. (1979) Identification of an enteric adenovirus by immunoelectroosmophoresis (IEOP) technique. J. Med. Virol. 3, 307-312.

Johansson, M.E., Uhnoo, I., Kidd, A.H., Madeley, C.R. and Wadell, G. (1980) Direct identification of enteric adenovirus, a candidate new serotype, associated with infantile gastroenteritis. J. Clin. Microbiol. 12, 95-100.

Johansson, M.E., Uhnoo, I., Svensson, L., Petterson, C.A. and Wadell, G. (1985) Enzyme-linked immunosorbent assay for detection of enteric adenovirus 41. J. Med. Virol. 17, 19-27.

Kidd, A.H. (1984) Genome variants of adenovirus 41 (subgroup G) from children with diarrhoea in South Africa. J. Med. Virol. 14, 49-59.

Kidd, A.H., Banatvala, J.C. and De Jong, J.C. (1983) Antibodies to fastidious faecal adenovirus (species 40 and 41 ) in sera from children. J. Med. Virol. 11, 333-341.

Kidd, A.H., Berkowitz, F.E., Blaskovic, P.J. and Schoub, B.D. (1984) Genome variants of human adenovirus 40 (subgroup F). J. Med. Virol. 14, 235-246.

Kidd, A.H., Harley, E.M. and Erasmus, M.E. (1985) Specific detection and typing of adenovirus types 40 and 41 in stool specimens by dot-blot hybridization. J. Clin. Microbiol. 22, 934-939. 
Norrby, E. (1969) The structural and functional diversity of adenovirus capsid components. J. Gen. Virol. $5,221-236$.

Osterhaus, A.D.M.E., Van Wezel, A.L., Van Steenis, G., Drost, G.A. and Hazendonk, T.G. (1981) Monoclonal antibodies to poliovirus. Production of specific monoclonal antibodies to the Sabin vaccine strains. Intervirology 16, 218-224.

Osterhaus, A.D.M.E., Van Wezel, A.L., Hazendonk, T.G., Uyt de Haag, F.G.C.M., Van Asten, J.A.A.M. and Van Steenis, G. (1983) Monoclonal antibodies to polioviruses. Comparison of intratypic strain differentiation of poliovirus type 1 using monoclonal antibodies versus cross-absorbed antisera. Intervirology 20, 129-136.

Osterhaus, A.D.M.E., Weijers, T.F., Bijlsma, K., De Ronde-Verloop, F.M., Van Asten, J.A.A.M. and De Jong, J.C. (1984) Comparison of monoclonal antibodies with ferret sera for the characterization of influenza A (H3N2) virus strains in a computer system. Dev. Biol. Stand. 57, 245-250.

Retter, M., Middleton, P.J., Tam, J.S. and Petric, M. (1979) Enteric adenovirus. Detection, replication and significance. J. Clin. Microbiol. 10, 574-578.

Singh-Naz, N. and Naz, R.K. (1986) Development and application of monoclonal antibodies for specific detection of human enteric adenoviruses. J. Clin. Microbiol. 23, 840-842.

Singh-Naz, N., Rodriquez, W.J., Kidd, A.H. and Brandt, C.D. (1988) Monoclonal antibody enzyme-linked immunosorbent assay for specific identification and typing of subgroup $\mathrm{F}$ adenovirus. J. Clin. Microbiol. 26, 297-300.

Sokal, R.R. and Sneath, P.M.A. (1963) In Principles of Numerical Taxonomy, pp. 305-333. W.H. Freeman, San Francisco.

Takiff, H.E., Straus, S.E. and Garon, C.F. (1981) Propagation and in vitro studies of previously non-cultivable enteral adenoviruses in 293-cells. Lancet ii, 832-834.

Takiff, H.E., Reinhold, W., Garon, C.F. and Straus, S.E. (1984) Cloning and physical mapping of enteric adenoviruses (candidate types 40 and 41 ). J. Virol. 51, 131-136.

Uhnoo, I., Wadell, G., Svensson, L. and Johansson, M. (1983) Two new serotypes of adenoviruses causing infantile diarrhea. Dev. Biol. Stand. 55, 311-318.

Uhnoo, I., Wadell, G., Svensson, L. and Johansson, M. (1984) Importance of enteric adenoviruses 40 and 41 in acute gastroenteritis in infants and young children. J. Clin. Microbiol. 20, 365-372.

Van der Avoort, H.G.A.M., Adrian, T., Wigand, R., Wermenbol, A.G., Zomerdijk, T.P.L. and De Jong, J.C. (1986) Molecular epidemiology of adenovirus type 21 in The Netherlands and the Federal Republic of Germany from 1960 to 1985. J. Clin. Microbiol. 24, 1084-1088.

Van Loon, A.E., Rozijn, Th.H., De Jong, J.C. and Sussenbach, J.S. (1985) Physicochemical properties of the DNAs of the fastidious adenovirus species 40 and 41 . Virology 140, 197-200.

Van Loon, A.E., Lichtenberg, M., Reemst, A.M.C.B., Sussenbach, J.S. and Rozijn, Th.H. (1987) Structure and organization of the left terminal regions of adenovirus types 40 and 41 DNA. Gene 58, 109-126.

Wadell, G. and De Jong, J.C. (1980) Restriction endonucleases in identification of a genome type of adenovirus 19 associated with keratoconjunctivitis. Infect. Immun. 27, 292-296.

Wadell, G., De Jong, J.C. and Wolontis, S. (1981) Molecular epidemiology of adenovirus: Alternating appearance of two different genome types of adenovirus 7 during epidemic outbreaks in Europe from 1958 to 1980 . Infect. Immunol. $34,368-372$.

Wadell, G., Cooney, M.K., Da Costa Linhares, A., Lakshman de Silva, Kenneth, M.L., Kono, R., Gui Fang, R., Lindeman, K., Nascimento, J.P., Schoub, B.D. and Smith, C.D. (1985) Molecular epidemiology of adenovirus: Global distribution of adenovirus 7 genome types. J. Clin. Microbiol. 21, 403-408.

Wadell, G., Allard, A., Johansson, M., Svensson, L. and Uhnoo, I. (1987) Enteric Adenoviruses in Novel Diarrhoea Viruses, Ciba Symposium, pp. 63-101. J. Wiley and Sons, Chichester, U.K.

Weijers, T.F., Osterhaus, A.D.M.E., Beyer, W.E.P., Van Asten, J.A.A.M., De Ronde-Verloop, F.M., Bijlsma, K. and De Jong, J.C. (1985) Analysis of antigenic relationships among influenza virus strains using a taxonomic cluster procedure. Comparison of three kinds of antibody preparations. J. Virol. Methods 10, 241-250.

Wigand, R. and Adrian, Th. (1986) Classification and epidemiology of adenoviruses. In: W. Doerfler (Ed.), Adenovirus DNA. The Viral Genome and its Expression, pp. 409-441. Martinus Nijhoff Publishers, Boston/Dordrecht/Lancaster. 